Dmytrenko M.Y., Dr. Habil (Pholisophy), professor, Cherkasy educational and scientific institute of the state higher educational establishment "University of Banking"

\title{
MODERN PARADIGM OF CORPORATE CULTURE AND MULTICULTURALISM
}

The author investigates the modern paradigm of corporate culture and multiculturalism. The interconnection of current cultural processes and the process of modern corporate culture development has been grounded theoretically. Historical prerequisites of the notions "multicultural society" and "multiculturalism" appearance are analyzed. The changes in the paradigm of the modern corporate society values are highlighted.

Keywords: corporate culture, multiculturalism, multicultural society, cultural processes, civilization.

Being a multifaceted socio-cultural phenomenon of the Late Modern period, corporate culture is based on the values of professionalism and serves as a catalyst for innovative reforms. The so-called "human factor" starts occupying the leading position. The following vision allows to broaden the horizons of understanding cultural dimension of corporatism, and implement the conceptualization of cultural representations on the macro level of theoretical reflection. Under the conditions of the development of a fundamentally new socio-cultural reality of post-industrial model, corporate culture ceases to be an extremely narrow local cultural form, acquiring a global dimension. Formation of a new world order that promotes a combination of the world unity in the diversity of its components is a priority of modern civilization. The constructive potential of multiculturalism gives all grounds for hope for a change in the paradigm of the modern corporate society values.

The study of the problems of cultural phenomena philosophical study in general and corporate culture in particular was reflected in the works of such national philosophers on theory and history of culture, philosophy of culture, philosophical anthropology, history, philosophy, ethics, aesthetics and philosophy of education as V. Andrushchenko, T. Andrushchenko, V. Bekh, E. Bystritskyi, E. Bilchenko, V. Bondarenko, V. Vashkevych, I. Drobot, Y. Kalynowskyi, V. Kremen, M. Kultaieva, S. Kutsepal, G. Miednikova, L. Panchenko, M. Rozumnyi, V. Yaroshovets, etc. But some theoretical and methodological problems of corporate culture, including the development of the modern paradigm of corporate culture and multiculturalism still remain unexplored.

The article is aimed at theoretical substantiating of the impact of cultural processes in social development, on the change of the modern paradigm of corporate culture and multiculturalism.

We can state that cultural differences in modern society, which is organized in the form of states has neither disappeared nor even smoothed. Moreover, it appears to show a vivid tendency to increase. It explains the rise of the interest to the problems associated with the multiculturalism. Along with the tendency of the integration of national states to such transnational associations as the European Union there is an existing tendency of national particularism, which clearly demonstrated its strength during the disintegration of the communist bloc. Strange as it may seem, but similar tendencies of disintegration distinguished themselves within the framework of the European Union during the national referendum on the draft of the Constitution. The features of religious fundamentalism are also evident in today's society. 
The analysis of theoretical sources and practical experience shows that the priority development of the modern civilization lies in the formation of a new world order that promotes the combination of world unity in the diversity of its components. And this diversity is manifested in various ways: in forming the national identity or sometimes even in deliberate cosmopolitanism; in choosing person's lifestyle in terms of private life or the area of voluntary associations.

To characterize the new world order appears a new concept of "global civilization" as a special cultural and historical form, expressing the coexistence of all cultural forms that have developed a single, albeit constantly changing, mosaic, collage picture of the modern world. The current situation of cultural diversity is explained in terms of cultural pluralism and multiculturalism.

The terms "multicultural society" and "multiculturalism" appeared in a political context and were originally related to immigration. They emerged in Canada in 1960s during the search for ways to resolve the situation and control the bicultural (English-French) country. Multiculturalism was a reaction to the actions of the Royal Commission on bilingualism and biculturalism (1963), which was trying to reach a new English-French compromise.

In 1970 Canada and Australia have started viewing multiculturalism as their official policy. In October 1971 the federal government made a formal declaration of multiculturalism as a goal of public policy. In 1989 the national program was declared in support of multicultural Australia. Preservation of the cultural heritage of minorities and improvement of intergroup relationships were emphasized.

Multiculturalism interpreted the reality of cultural differences as the result of political order. It meant the development of rules and norms of coexistence of different cultures and their representatives in one single society, a single legal, social and economic field. In this context multiculturalism has put a number of basic questions regarding the dominant legal theories and political order. On the global level the most urgent task was determined as peaceful coexistence of different modes based on different cultural traditions. The book by Charles Taylor "Multiculturalism and the Politics of Recognition" laid the foundation in building the concept of multiculturalism as a field of liberal political theory.

It was quite natural that multiculturalism was not only the focus of ideological and political differences, but the discussions and developments in the field of social theory and philosophy.

O. Spengler was the first in the philosophy of culture to overcome the monotheistic, Eurocentric historical scheme of thought that prevailed in the European consciousness of modern times. In contrast to the traditional system of history that considered cultural development as the rotation around an imaginary center of Europe, O. Spengler distinguishes many cultures as separate worlds that have the same meaning in the overall cultural and historical development [1]. Each of these equal and equitable cultural forms must have "its own idea, its own passions, its own life, will and feeling, its own death" [2, p. 151]. He calls this view "the Copernican discovery" in the philosophy of culture.

Scientists of the 20th century point to the fact that the interaction of cultures was typical throughout history, although at different stages it had different nature. This, in particular, was mentioned by U. Eco, who draws parallels between today and the Middle Ages. There has been a grand cultural confusion since then. According to U. Eco, Europe can become the continent of the colored in one hundred years. This is another reason why we should be ready to accept cultural diversity, mixing of different nations, to accept this "mess, otherwise we will fail" [3, p. 91].

Separation of civilizations into independent and satellites can be found in the works by Arnold Toynbee. Satellite civilizations, which have the same identity, absorb a significant share of other cultural entities. However, A. Toynbee pointed out that their selection is a rather complicated typological problem [4, p. 487]. 
Cultural and historical processes show that dependence and autonomy are not strictly specified characteristics of civilizations not only on the examples of Italian, but also Japanese, Russian and other civilizations. The status of any socio-cultural formation is capable of change.

In this regard it should be noted that the degree of mainstreaming in socio-cultural dynamics of different trends vary. Thus, in the periods of stability any local culture is usually self-sufficient and the process of borrowing the values of other cultures, initiation to their experience elevates almost to a minimum. However, this period is broken in the course of time because of various reasons. The society is not satisfied with the usual forms of culture that are conservative, inadequate, inert and do not keep the pace with the changed life reality.

Swedish researcher Göran Therborn distinguishes four types of multicultural societies in terms of origin and social dynamics. "These are empires that existed before the modern era: the New World settlements, colonial and ex-colonial societies and post-national multiculturalism in recent North America, Oceania, and Western Europe" [5, p. 50].

G. Therborn relates the modern concept of multiculturalism to modern Western Europe, North America and Oceania. Its specificity is the one generated by the cultural dynamics that was neither pre-national as in pre-modern empires, nor the one that creates the nation, as in the New World and ex-colonial area. It is post national because it appeared after the creation of nations and deploys within the national states. Its development is linked to the modernization processes, the spread of higher education in 1960s, a new audiovisual, music and print-replicable mass culture, with the emergence of corporate culture [6, p. 74-83].

It is likely that the process of expanding the geographical boundaries of post national multicultural societies coincides with the processes of modernization and rapid promotion of corporate culture in the cultural and historical space and thus, becomes global. In today's world the nature of interaction between cultures is also changing. Currently existing post national multiculturalism is much more volatile compared with static multicultural communities of pre-modern empires and it is more dynamic, which is certainly due to the increase in the volume and speed of movement of the information.

Imperial political communities and universalistic religious and ideological views were the main integration forces in the traditional society. It lasted up to the era of modern times when Western civilization became the obvious leader in world history. These communities and views were able to rally people together, giving their lives a global semantic perspective. When Western civilization started playing the leading role, rational technology of social life including cultural forms of corporate culture became of vital importance for the integration process.

Specificity of modern cultural processes makes them look for a new conceptual expressions. Thus, Arnold Toynbee uses the term "technological civilization", as opposed to the type of traditional civilization processes. G. Therborn mentions "cultural hybridization". French researcher A. Moles introduces the term "mosaic culture" and talks about the process of ousting the traditional "humanitarian" " culture of the past with the new one under the influence of mass media.

Information theoretical approach to the analysis of the phenomena of modern culture, initiated by A. Moles, allowed him to develop the concept of "mosaic culture" emerging as the prototype of the future model of culture of postmodernism in its virtual version. The difference between the traditional culture and the mosaic culture was seen in the fact that the first one was formed under the influence of a rationally organized learning process, usually through sustainable educational system and the second one was shaped by continuous, heavy and chaotic flow of information disseminated mainly by means of mass communication. "We shall call this culture "mosaic" because it is random and composed of many fragments that collide, but do not form a construction. It is the result of the daily flow of random data" [7, p. 60].

A special role of corporate culture in shaping specific multicultural situations of 20th century was noted by Canadian philosopher and sociologist H. McLuhan [8]. He proved the mosaic nature of 
modern corporate culture by the impact of the phenomena that evolve in the course of scientific and technological progress on the consciousness of a modern man. He considered modern communication to demonstrate a valid mosaic of events occurring simultaneously.

As for the postmodern ideologues, they gave a positive assessment of the fragmentation of contemporary culture. Having rejected the search for the true essence, postmodernists believe that fragmentation is good, because people can just get pleasure, forgetting about the incompatibility of meanings and images. The combination of the incompatible is done on the playground. It means information and communication culture.

M. Bakhtin's idea of dialogic consciousness is well-known. This phenomenon appears to be characteristic not only of the individual consciousness, but of the modern society. D. Likhachev shares his idea by analyzing the context of corporate culture of the early 20th century, which is characterized by the counterpoint of styles.

Having analyzed the process of corporate culture paradigm development in the terms of philosophy, we can point out that, on the one hand, the so-called Western model has a strong effect on establishing Ukraine's corporate culture. On the other hand it adapts to Ukrainian realities becoming even more beneficial. Despite the fact that they are absolutely different, they prove to have a lot in common. One of the key points lies in the principle of pluralism of cultural forms which is fundamental for explaining modern corporate culture. Under these conditions Eurocentric modernism is characterized by intentions, postmodernism is oriented on polycentric culture in all its manifestations. Collage, which originated as a private artistic practice, is transformed into a postmodern method of corporate culture.

It should be noted that the fragmentation of corporate culture has a destructive effect on the dialogue and communication relations and overall semantic space. Losing its uniting semantic center, the dialogue of corporate cultural forms is eroded by all sorts of interpretations; it loses its inherent tensions and is replaced by random mixing [9]. Moral and aesthetic opposites and restrictions are not a barrier.

It is no wonder that one of the most significant problems in the philosophy of Late Modern is the dialogue. Originally it was opposed to the monologue "I"of the classical tradition and was associated with the idea of the freedom of choice. In the process of establishing the dialogue between people and between cultures there raises the question of how to understand the "Other" as a subject with his own experience if the existence and nature of the experience of another cannot be verified.

Philosophy of the dialogue, developed in the 20th century, generally leads to radical epistemological changes: its introduction into modern thinking undermines fundamentalism, while keeping the foreground culture as identity. The cultural mosaic, free combination of different standards of abstract thought, ways of communication in the postmodernist era of life does not mean the disappearance of the individual identities of cultural forms. On the contrary, under the influence of this trend there is a surge of interest in the acquisition of a new version of self-identity. Although in today's world it is becoming a phenomenon of "global civilization" and "corporate culture" as a type of cultural product. We cannot speak of the "world culture" as a single, coherent concept. There remains a communicative dialogue of cultural forms in the place of this hypothetical phenomenon.

Conclusion. In our opinion, it is the result of the very essence of culture, which is inextricably linked with the creative activity of the subject, both external and internal, aimed at spiritual and moral development. In a broad sense, subject of the cultural and historical process is the nation. It is possible to speak about its merger into a single entity only in terms of the political context. That's why we have come to the conclusion that modern corporate culture is presented as a dialogue and interaction between cultural forms, as the situation of multiculturalism, not as their unification (template mass culture). We do not exclude that in the future there may appear the global phenomenon of human society as a single entity of cultural and historical process. 
Thus, it is clear that multiculturalism has a modern constructive and not destructive potential, which allows us to hope for a change in paradigm of values characteristic of the modern corporate society suffering earthiness of the values and traits of anti-humanism. Notably, an outstanding representative of structuralism in the modern anthropology Levi-Strauss sees new possibilities of understanding the human communication and new stage of humanity in the modern society [10, p. 296].

Noting the high potential of humanistic multiculturalism as one of the most important features of contemporary cultural situation, we believe that it forms one of the reasons for the optimistic scenario of the culture as a whole, including corporate culture as its form.

In our opinion corporate culture and multiculturalism are interrelated phenomena because they are the result of globalization, technological and information processes. Due to its communicative forms corporate culture easily discovers new cultural space acting both as a means of implementing multiculturalism and, simultaneously, as a driving force of its development. Despite the versatility of its essential features, corporate culture does not lead to a complete cultural unification. The study of communicative aspect of corporate culture can be seen as one of the prior directions of further research as it will promote the formation of a new subject of the communicative space of the corporation and thus, help to overcome the spiritual crisis.

\section{References}

1. Stockton D. The Oswald Spengler Collection: Biographical Essay; Extracts From The Decline Of The West; The Hour Of Decision, available at: http://www.cakravartin.com/wordpress/wpcontent/uploads/2007/02/spengler-oswald-the-decline-of-the-west.pdf

2. Spengler O. Zakat Yevropy [The decline of the West]. Moscow, Pg., 1923, Vol. I, pp. 128-344 [in Russian]

3. Kearney R. Dialogi o Yevrope [States of Mind: Dialogues with Contemporary Thinkers on the European Mind]. Moscow, 2002, p. 91 [in Russian]

4. Toynbee A.J. A Study of History. London, 1988, p. 487.

5. Therborn G. Multikulturnye Obshchestva [Multicultural societies]. Sotsiologicheskoye obozrenie - Sociological Review, 2001, Vol. 1, No. 1, p. 50 [in Russian]

6. Therborn G. European Modernity and Beyond, The Trajectories of European Societies. L., Sage, 1996, $416 \mathrm{p}$.

7. Simmel G. Izbrannoye: $v 2 t$. [Selected works: in 2 vol.]. Moscow, 1996, 607 p. [in Russian]

8. McLuhan M. The Gutenberg Galaxy: The Making of Typographic Man. Toronto, 1967, $330 \mathrm{p}$.

9. Terrence D., Kennedy A. Corporate Cultures: The Rites and Rituals of Corporate Life. Perseus Books Group, 2000, 232 p.

10. Levi-Strauss C. Tri vida gumanizma [Three types of humanism]. Yezhegodnik filosofskogo obshchestva SSSR (1987-1988) - The USSR Philosophical Society Yearbook (1987-1988). Moscow, 1989, p. 296 [in Russian]

Отримано 02.06.16 
Дмитренко М.Й., професор, д-р філософських наук, завідувач кафедри соціально-гуманітарних дисциплін, Черкаський навчально-науковий інститут ДВНЗ «Університет банківської справи»

\section{СУЧАСНА ПАРАДИГМА КОРПОРАТИВНОЇ КУЛЬТУРИ І МУЛЬТИКУЛЬТУРАЛІЗМУ}

Досліджено сучасну парадигму корпоративної культури та мультикультуралізму. Теоретично обтрунтовано взаємозв'язок сучасних культурних процесів $і$ процесу становлення сучасної корпоративної культури. Проаналізовано історичні передумови виникнення понять «мультикультурне суспільство» $i$ «мультикультуралізм». Висвітлено зміни иіннісної парадигми сучасного корпоративного суспільства.

Ключові слова: корпоративна культура, мультикультуралізм, мультикультурне суспільство, культурні прочеси, циивілізація.

Дмитренко М.И., профессор, д-р философских наук, заведующий кафедрой социальногуманитарных дисциплин, Черкасский учебно-научный институт ГВУЗ «Университет банковского дела»

СОВРЕМЕННАЯ ПАРАДИГМА КОРПОРАТИВНОЙ КУЛЬТУРЫ И МУЛЬТИКУЛЬТУРАЛИЗМА Исследована современная парадигма корпоративной культуры и мультикультурализма. Теоретически обоснована взаимосвязь современных культурных прочессов и прочессов становления современной корпоративной культуры. Проанализированы исторические предпосылки возникновения понятий «мультикультурное общество» и «мультикультурализм». Раскрыты изменения ценностной парадигмы современного корпоративного общества.

Ключевые слова: корпоративная культура, мультикультурализм, мультикультурное общество, культурные процессы, циивилизация. 